\title{
The Bristol Stool Form Scale: its translation to Portuguese, cultural adaptation and validation
}

\author{
Anna Paula Martinez ${ }^{1}$ \\ Gisele Regina de Azevedo²
}

The Bristol Stool Form Scale is used for describing feces. The objective of this research was its translation, cultural adaptation and validation for Brazil. The methodology was translation, back-translation and discussion. Validation involved 85 nurses, 80 doctors, and 80 patients, who correlated images of seven types of feces with the descriptions. Results: there was a difference in sex distribution, with males predominating among the doctors and females among nurses and patients. In relation to concordance between definitions and pictures, the highest percentage was in type 5 in all three groups and the lowest was in types 6 and 7 for the doctors, in type 3 for the nurses, and type 6 for the patients. The general Kappa index was 0.826. Conclusion: the scale demonstrated high reliability for all the groups studied.

Descriptors: Translation; Validation Studies; Stools.

\footnotetext{
${ }^{1}$ Master's student, Faculdade de Ciências Médicas e da Saúde, Pontifícia Universidade Católica de São Paulo, Brazil. Scholarship holder of the Scientific Initiation Program at the Conselho Nacional de Desenvolvimento Científico e Tecnológico (CNPq).

2 PhD, Assistant Professor, Faculdade de Ciências Médicas e da Saúde, Pontifícia Universidade Católica de São Paulo, Brazil.
} 


\title{
Tradução, adaptação cultural e validação da Bristol Stool Form Scale para a população brasileira
}

\begin{abstract}
A Escala de Bristol para Consistência de Fezes é usada na descrição de fezes. O objetivo deste estudo foi realizar a tradução, adaptação cultural e validação para o Brasil, dessa escala. Como metodologia realizou-se a tradução, tradução reversa e discussão. Para essa validação, incluíram-se 85 enfermeiros e 80 médicos e pacientes que correlacionaram imagens de sete tipos de fezes com descrições. Os resultados mostraram que houve diferença de distribuição do sexo, com predomínio do sexo masculino para médicos e feminino para enfermeiros e pacientes. Em relação à concordância entre definições e imagens, o maior percentual, no tipo 5, e os menores percentuais, nos tipos 6 e 7, relacionaram-se aos médicos; no tipo 3 referiram-se aos enfermeiros e no tipo 6 aos pacientes. 0 índice Kappa geral foi de 0,826. Conclui-se que a escala demonstrou alta confiabilidade em todos os grupos estudados.

Descritores: Tradução; Estudos de Validação; Fezes.
\end{abstract}

\section{Traducción, adaptación cultural y validación de la "Bristol Stool Form Scale"}

La "Bristol Stool Form Scale" es usada para describir las heces. Objetivo: traducción, adaptación cultural y la validación para ser utilizada en Brasil. Metodología: Fue realizada la traducción, la traducción inversa y la discusión final. Para validar, se incluyeron 85 enfermeros y 80 médicos y pacientes que correlacionaron diseños de siete tipos de heces con descripciones. Resultados - Hubo diferencia en cuanto a la distribución del sexo con predominio masculino entre los médicos y femenino para los enfermeros y pacientes. Con respecto a la concordancia entre los conceptos y las imágenes, la mayor concordancia fue del tipo 5 en cuanto que el de menor correspondencia para los médicos fueron los tipos 6 y 7, para los enfermeros el 3 y el 6 para los pacientes. El índice de Kappa general fue de 0,826. Conclusión: Los valores obtenidos demuestran la alta confiabilidad de este cuestionario con respecto a los grupos estudiados.

Descriptores: Traducción; Estudios de Validación; Hece.

\section{Introduction}

Analysis of bowel habits and feces type has always been part of evaluations carried out by healthcare professionals for characterizing physiological aspects of patients, as well as in the diagnosis or follow-up of diseases which involve alterations in intestinal transit.

In physiological situations, the characterization of feces can be quite useful. For example, the relationship with the type of diet and bowel habits and the resulting form of the feces has been explored in the literature ${ }^{(1-3)}$.

In relation to the diagnosis and medical supervision, on the other hand, one can cite its importance in anal incontinence (AI), irritable bowel syndrome, and in the post-operative stage after abdominal surgery, among others ${ }^{(4-7)}$.

Anal function declines with age and women experience a greater functional loss than men(8). Anal incontinence is frequent during the menopause and lesions sustained during childbirth increase the risk of compromise of anal function ${ }^{(8)}$. A significant portion of this compromise is purely the result of aging( ${ }^{(8)}$.
Anal incontinence can be idiopathic, congenital, of neurological origin or secondary to trauma(9). According to the Rome II Criteria, AI can be classified as light, characterized by loss of gases or soiling; moderate, with the loss of mushy or liquid feces up to three times per week, and severe, when there is total incontinence with loss three or more times per week ${ }^{(10-14)}$.

Another condition which is characterized by alterations in the form of the feces is Irritable Bowel Syndrome ${ }^{(15)}$, which is functional by nature and which has as its principal symptoms abdominal pain and discomfort, related to alteration in bowel habits ${ }^{(15-17)}$ Another area where analysis of feces can be useful is in the post-operative stage of treatment for gastro-intestinal illnesses ${ }^{(18)}$.

Some instruments are utilized to help in classification and treatment ${ }^{(19-20)}$; one which stands out is the Bristol Stool Form Scale (BSFS), which was developed and validated by Kenneth W. Heaton and S. J. Lewis. Its objective is to descriptively evaluate the form of fecal content, using graphic methods which represent seven types of feces according to 
their shape and consistency. The innovation of this scale is that it presents images which illustrate the feces, along with precise descriptions as to the shape and consistency, using easily recognizable examples ${ }^{(21)}$. All the patient has to do is select the type of feces which most resembles his or her own, according to their shape and consistency (21-22).

The BSFS was validated in its original version in English and has been translated, adapted and validated in Spanish. Due to its simplicity and efficacy, it has been incorporated into clinical practice for the evaluation of patients with irritable bowel syndrome, HIV-diarrhea related, and anal incontinence, besides being a much-used instrument in scientific studies related to these ${ }^{(21,23)}$. To be used in Brazil, its translation, cultural adaptation and, consequently, validation are needed.

The objectives of the present study were the Bristol Stool Form Scale's translation into Portuguese, cultural adaptation, and validation, so that it might be used in Brazil.

\section{Method}

Permission for the translation, validation and adaptation of the Bristol Stool Form Scale was obtained from the company Norgine Ltd which holds copyright and use of the same, conceded by the authors. The study was approved by the Research Ethics Committee of the Medical Sciences and Health Faculty of the Pontifical Catholic University of São Paulo.

The scale is descriptive and visual, and consists of seven types of feces, being made up of images and their respective definitions:

-Type 1: Separate hard lumps, like nuts (hard to pass).

-Type 2: Sausage-shaped, but lumpy.

-Type 3: Like a sausage but with cracks on its surface.

-Type 4: Like an Italian sausage or snake, smooth and soft.

-Type 5: Soft blobs with clear cut edges (passed easily).

-Type 6: Fluffy pieces with ragged edges, a mushy stool.

-Type 7: Watery, no solid pieces. Entirely liquid.

\section{Translation and cultural adaptation}

The translation into Portuguese was undertaken by two specialists in digestive function disorders who spoke both languages well. Once the scale had been translated, some descriptions were modified, so as to adapt it to the language and culture of Brazil, such as in the cases of the words "nuts" - which to an English-speaker suggests hazelnuts ${ }^{1}$ and was substituted with the term coquinhos ${ }^{2}$, which supplies an analogous image - and "sausage" which, for different types, was translated with the words "lingüiça" (German-style sausage) and "salsicha" (wiener), for better comprehension across Brazil.
Following this, back translation was carried out by a different pair of bilingual specialists.

At this point, the Portuguese version was applied in a pilot test by nine people (three doctors, three nurses and three patients) to detect possible comprehension problems, and, after some final adjustments, the definitive version of the scale was obtained.

\section{Validation}

The definitive version (Figure 1) was applied to a sample of 165 healthcare professionals ( 80 doctors and 85 nurses) and 80 patients over 18 years of age, chosen at random from outpatient clinics at the Sorocaba Hospital Complex. All the evaluations were carried out in public health service facilities. The subjects were presented with a chart with the pictures representing the seven types of feces. Next, they were asked to match a text selected at random from the translated scale with one of the pictures. Ten per cent of the interviewees from each group (doctors, nurses and patients), chosen at random, were instructed to repeat the evaluation fifteen days later (re-test), to test its reproducibility.

\section{Statistical analysis}

1 - Comparison of the make-up of the groups, in relation to sex and level of schooling (descriptive analysis with $n$ and percentages).

2 - Description of the level of success and error in correlating images and their descriptions, using the absolute number of choices.

3 - Description of the total of the subjects evaluated, and of each group, in relation to their success in matching the images and the descriptions for each of the types of feces.

4 - Analysis of agreements between the groups (internal reliability and comparison between the groups).

5 - Analysis of the test-retest.

The size of the sample is calculated to estimate the concordance of $95 \%$, with $5 \%$ precision and $5 \%$ significance. The quantitative variables were described with averages and standard deviation and, in the case of the qualitative variables, with absolute numbers and percentages. The reliability was analyzed by means of percentage and through a Kappa index. The comparative analyses were carried out through Kendall's test of concordance for the percentage of agreement, and the Fleiss method was used for the Kappa values. The reproducibility after the period of 15 days was evaluated by means of the percentage of concordance and the Kappa index between the answers and a value below 0.05 was considered statistically significant.

\footnotetext{
1 To a Brazilian, the word 'nuts' suggests walnuts. Translator's note.

2 Small nuts from a type of coconut tree. Translator's note. 


\section{Escala de Bristol de Consistência de Fezes}

\begin{tabular}{|c|c|}
\hline Tipo 1 & $\begin{array}{l}\text { Pequenas bolinhas duras, separadas } \\
\text { como coquinhos (dificil para sair). }\end{array}$ \\
\hline Tipo 2 & $\begin{array}{c}\text { Formato de linguiça encaroçada, com } \\
\text { pequenas bolinhas grudadas. }\end{array}$ \\
\hline Tipo 3 & $\begin{array}{l}\text { Formato de linguiça com rachaduras } \\
\text { na superficie. }\end{array}$ \\
\hline Tipo 4 & $\begin{array}{l}\text { Alongada com formato de salsicha } \\
\text { ou cobra, lisa e macia. }\end{array}$ \\
\hline Tipo 5 & $\begin{array}{l}\text { Pedaços macios e separados, com } \\
\text { bordas bem definidas (fáceis de sair). }\end{array}$ \\
\hline Tipo 6 & $\begin{array}{c}\text { Massa pastosa e fofa, com } \\
\text { bordas irregulares. }\end{array}$ \\
\hline Tipo 7 & $\begin{array}{l}\text { Totalmente liquida, sem } \\
\text { pedaços sólidos. }\end{array}$ \\
\hline
\end{tabular}

Figure 1 - The Bristol Stool Form Scale adapted to Portuguese

\section{Results}

The study population was divided in groups according to their profession or whether they were patients. The first group was made up of doctors, who were mainly male. The second group was made up of nurses, who were mainly female. The majority of patients were also female. As for level of education, none of the patients had been educated at university level. The patients were chosen at random too, irrespective of their illness or which specialist they were being treated by. None of the patients had any cognitive deficiency which could influence the results. Table 1 shows the numerical distribution of the sample, related to sex.
Table 1 - Characteristics referent to the sex of the respondents who made up the sample. Sorocaba, São Paulo, Brazil, 2011

\begin{tabular}{ccccccc}
\hline \multirow{2}{*}{ Variables } & \multicolumn{2}{c}{ Doctors } & \multicolumn{2}{c}{ Nurses } & \multicolumn{2}{c}{ Patients } \\
\cline { 2 - 7 } & $\mathbf{n = 8 0}$ & $\%$ & $\mathbf{n = 8 5}$ & $\%$ & $\mathbf{n = 8 0}$ & $\%$ \\
\hline Sex (\%) & & & & & & \\
Male & 47 & 58.75 & 5 & 5.88 & 31 & 38.75 \\
Female & 33 & 41.25 & 80 & 94.12 & 49 & 61.25 \\
\hline
\end{tabular}

Table 2 shows the results for concordance or harmony (definition of text and image) for the validation text in all groups of individuals 
Table 2- Correspondence of responses between texts and images in all the series. Sorocaba, São Paulo, Brasil, 2011

\begin{tabular}{lccccccccc}
\hline & \multicolumn{7}{c}{ Images } & \multicolumn{1}{c}{ Total } \\
\cline { 2 - 7 } & $\mathbf{1}$ & $\mathbf{2}$ & $\mathbf{3}$ & $\mathbf{4}$ & $\mathbf{5}$ & $\mathbf{6}$ & $\mathbf{7}$ & \\
\hline 1 & 239 & 1 & 2 & 0 & 0 & 3 & 0 & 245 \\
2 & 1 & 218 & 11 & 6 & 0 & 7 & 2 & 245 \\
3 & 1 & 13 & 213 & 2 & 3 & 8 & 5 & 245 \\
4 & 0 & 2 & 1 & 239 & 0 & 1 & 2 & 245 \\
5 & 0 & 1 & 1 & 0 & 242 & 1 & 0 & 245 \\
6 & 1 & 3 & 5 & 0 & 0 & 213 & 23 & 245 \\
7 & 3 & 6 & 5 & 1 & 0 & 17 & 213 & 245 \\
Total & 245 & 244 & 238 & 248 & 245 & 250 & 245 & 1715 \\
\hline
\end{tabular}

Table 3 shows the concordance (as a percentage) between definitions and images in relation to the type of feces and the persons studied. The highest percentage for concordance was type 5 (100\% for doctors and nurses, and $96.3 \%$ for patients), and the lowest percentage was for types 6 and 7 for doctors (91.3\%), type 3 for nurses $(83.5 \%)$ and type 6 for patients $(82.5 \%)$.

Table 3 - Concordance between texts and images relating to feces type and persons studied

\begin{tabular}{lcccc}
\hline \multirow{2}{*}{ Feces type } & Doctors & Nurses & Patients & Total \\
\cline { 2 - 5 } & $\mathbf{n = 8 0}$ & $\mathbf{n = 8 5}$ & $\mathbf{n = 8 0}$ & $\mathbf{n = 2 4 5}$ \\
\cline { 2 - 5 } & $\%$ & $\%$ & $\%$ & $\%$ \\
\hline 1 & 98.8 & 98.8 & 95.0 & 97.6 \\
2 & 92.5 & 87.1 & 87.5 & 89.0 \\
3 & 92.5 & 83.5 & 85.0 & 86.9 \\
5 & 97.5 & 100.0 & 95.0 & 97.6 \\
6 & 100.0 & 100.0 & 96.3 & 98.8 \\
7 & 91.3 & 87.1 & 82.5 & 86.9 \\
\hline
\end{tabular}

The general Kappa index was 0.826, and the concordance summary for this index in each of the groups is presented in Table 4.

Table 4 - Concordance results for the global study. Sorocaba, Brazil, 2011

\begin{tabular}{lcccc}
\hline \multicolumn{1}{c}{ Variables } & Concordance & $\mathbf{p}^{*}$ & Kappa & $\mathbf{p}^{\dagger}$ \\
\hline Total group & $89.5 \%$ & $<0.0001$ & 0.826 & $<0.0001$ \\
Doctors & $93.0 \%$ & $<0.0001$ & 0.884 & $<0.0001$ \\
Nurses & $91.1 \%$ & $<0.0001$ & 0.825 & $<0.0001$ \\
Patients & $84.6 \%$ & $<0.0001$ & 0.773 & $<0.0001$ \\
\hline
\end{tabular}

* Kendall's concordance test; ${ }^{\dagger}$ Fleiss method.

In the retesting phase there were no errors and, therefore, there was perfect concordance irrespective of the group.

\section{Discussion}

The form of feces is modified in various intestinal illnesses such as, for example, infectious diarrheas, colitides, constipation, anal incontinence and irritable bowel syndrome ${ }^{(14-15)}$. Its description in the medical history can be determinant in the diagnosis and medical supervision of these illnesses associated with other characteristics of bowel movements ${ }^{(14)}$. Its use as a parameter for improvement or worsening can facilitate the healthcare professional's dealing with these pathologies. This description varies according to the patient's language and its interpretation also depends on the healthcare professional's experience.

It is, however, very difficult to obtain a precise description of the appearance and consistency of feces, which is why Heaton and Thompson created a visual and descriptive scale called "The Bristol Stool Form Scale", which has been widely used, so as to guarantee that the patients describe their own fecal form precisely ${ }^{(15)}$. The translation, validation and cultural adaptation of health evaluation instruments, as with this scale, is important for making it possible to carry out multinational studies or for comparing data from different Brazilian studies ${ }^{(17)}$.

The Bristol Scale has been recognized in the literature as a valuable instrument in the evaluation of intestinal illnesses, leading to a need for its translation and validation. This process has already been carried out for English and Spanish, allowing the opportunity for its use on an international level and for the comparison of data from various research centers in countries with the latter language ${ }^{(23)}$.

This study was based on validation processes accepted worldwide and the methodology was divided into translation, cultural adaptation and validation. In this process, it was judged that cultural adaptation is the most important stage, as - apart from the language - the local culture can influence the form of expression. After translation, practically all of the items were modified to some degree so as to facilitate understanding. 
The sample made up of health care professionals was considered the most accurate in relation to the instrument's being understood, as it was observed that there was a high correlation among the results, compared to a sample made up of non-health care respondents. As the instrument was devised to be used irrespective of educational level, it may be inferred that this difference between the groups is related to their knowledge about the area of health. The absence of any patients educated at university level reflected the reality of that hospital unit, which acts as a tertiary referral center for a low-income population of this region of the state of São Paulo. The rate of correlation obtained was higher than what the researchers had expected, which shows the care taken in the phases of translation and cultural adaptation.

The comparison between the results obtained in this study and in that undertaken for the validation of the Spanish-language version differs significantly, despite similarity in relation to the number of persons studied(23).

The samples are similar in relation to demographic data (being aged over 18, predominance of females). In relation to the type of feces most accurately identified, differences may be observed as much in the total of evaluations as in each group, although a high percentage of correct identification was observed in both studies. The types of feces with the greatest degree of correct or incorrect identification among the three groups were different in the two studies. In the Brazilian study, the type of feces most correctly identified was type 5, and the least correctly identified was type 6; while in the Spanish study, it may be observed that the most correctly identified type was type 4 and the least correctly identified was type 5 . This fact is attributed to the difference in language and expressions used for the description of feces in professional and lay circles.

In relation to the three groups studied, the Brazilian doctors obtained a higher rate of correct identification for type 5, whereas the Spanish doctors were more likely to correctly identify types 2 and 7. The Brazilian nurses were most likely to identify types 4 and 5 , while the Spanish nurses tended to correctly identify type 6. Lastly, the Brazilian patients correctly identified type 6 most, whereas the Spanish patients correctly identified type 4 most.

With regard to reliability, measured by the percentage of concordance between image and definition and the Kappa index, this study showed higher values than obtained by the Spanish group.

\section{Conclusion}

The Bristol Stool Scale for the Consistency of Feces, translated and validated for Portuguese for use in Brazil, showed high reliability, indicating its usefulness in clinical practice for the purpose for which it was devised.

\section{Acknowledgments}

We thanks Jessica Clementino for their assistance on the data collection.

\section{References}

1. Saad RJ, Rao SS, Koch KL, Kuo B, Parkman HP, McCallum RW, Sitrin MD, Wilding GE, Semler JR, Chey WD. Do stool form and frequency correlate with whole-gut and colonic transit? Am J Gastroenterol. 2010 Feb;105(2):403-11

2. Heaton KW, Radvan J, Cripps H, Mountford RA, Braddon $\mathrm{FE}$, Hughes AO. Defecation frequency and timing, and stool form in the general population: a prospective study. GUT. 1992;33:818-24.

3. Degen LP, Phillps SF. How well does stool form reflect colonic transit? GUT. 1996;39:109-13.

4. López G, Antonio J. Incontinência anal/ Anal incontinence. Iatreia. 2002;15(3):190-9.

5. Engsbro AL, Simren M, Bytzer P. Short-term stability of subtypes in the irritable bowel syndrome: prospective evaluation using the Rome III classification. Aliment Pharmacol Ther. 2012 Feb;35(3):350-9.

6. Palsson OS, Baggish JS, Turner MJ, Whitehead WE. IBS Patients Show Frequent Fluctuations Between Loose/Watery and Hard/Lumpy Stools: Implications for Treatment. Am J Gastroenterol. 2012 Feb;107(2):286-95.

7. Domansky RC. Avaliação do hábito intestinal e fatores de risco para incontinência anal na população geral [tese de doutorado]. São Paulo (SP). São Paulo: Escola de Enfermagem da Universidade de São Paulo; 2009. 125 p. 8. Martínez ECJ, Flores CO, García JE, Velázquez PI, González MI, Márquez RA. Prevalence of urinary and anal incontinente in women from metropolitan area of Guadalajara. Ginecol Obstet Mex. 2006;74(6):300-5.

9. Bemonte-Monte C, Cervera-Servín JA, García-Vázquez $J \mathrm{~L}$. Fecal incontinence, occult lesions to the anal sphincter and related factors in primiparous patients without median routine episiotomy. Cir Cir. 2006;74(6):449-55.

10. Martínez P, Godínez MA, Rivas E, Herrera D, Barrón R. Anal incontinence caused by an obstetric trauma. Experience with the technique of overlapping sphincteroplasty. Ginecol Obstet Mes. 2006;74(8):418-23.

11. Azevedo GR, Negri AF. Dispositivo para Incontinência anal. Estima. (Sociedade Brasileira de Estomaterapia). 2007;5:40-2.

12. Alós R, Solana A, Ruiz MD, Moro D, García-Armengol J, Roig-Vila JV. Novel techniques in treatment of anal incontinence. Cir Española. 2005;78(3):41-9.

13. Lumi CM, Munoz JP, La Rosa L. Neuromodulación sacra para el tratamiento de la incontinencia anal. Experiencia piloto prospectiva en Argentina/ Sacral neuromodulation 
in fecal incontinente. The pilot prospective experience in Argentina. Acta Gastroenterol Latinoam. 2007;37(1): 29-36.

14. Whitehead WE, Wald A, Norton NJ. Treatment options for fecal incontinence. Dis Colon \& Rectum. 2001;44(1):131-42.

15. Yilmaz S, Dursun M, Ertem M, Canoruc F, Turhanoglu A. The epidemiological aspects of irritable bowel syndrome in Southeastern Anatolia: a stratified randomised community-based study. Int J Clin Pract. 2005;59:361-9. 16. Longstreth GF, Thompson WG, Chey WD, Houghton LA, Mearin F, Spiller RC et al. Functional Bowel Disorders. Gastroenterology. 2006;130:1480-91.

17. Heaton KW, Ghosh S, Braddon. How bad are the symptoms and bowel dysfunction of patients with the irritable bowel syndrome? A prospective, controlled study with emphasis on stool form. GUT. 1991;32:73-9.

18. Hearing SD, Thomas L, Heaton K, Hunt L. Effect of cholecystectomy on bowel function: a prospective, controlled study. GUT. 1999;45:889-94.

19. Macmillan AK, Merrie AE, Marshall RJ, Parry BR. Design and validation of a comprehensive fecal incontinence questionnaire. Dis Colon Rectum. 2008;51(10):1502-22. 20. Yusuf SA, Jorge JM, Habr-Gama A, Kiss DR, Gama J. Evaluation of quality of life in anal incontinence: validation of the questionnaire FIDL (Fecal Incontinence Quality of Life). Arq Gastroenterol. 2004;41(3):202-8.

21. Peréz MM, Martínez AB. The Bristol scale - a useful system to assess stool form? Rev Esp Enferm Dig. 2009;101(5):305-11.

22. Riegler G, Esposito I. Bristol scale stool form. A still valid help in medical practice and clinical research. Tech Coloproctol. 2001;5(3):163-4.

23. Parés $D$, Comas $M$, Dorcaratto $D$, Araujo MI, Vial M, Bohle $B$, et al. Adaptation and validation of the Bristol scale stool form translated into the Spanish language among health professionals and patients. Rev Esp Enferm Dig. 2009;101(5):312-6. 